\title{
Borrelia miyamotoi Infections in Small Mammals, California, USA
}

\author{
Daniel J. Salkeld, ${ }^{1}$ Nathan C. Nieto, ${ }^{1}$ \\ Denise L. Bonilla, ${ }^{2}$ Melissa H. Yoshimizu, \\ Kerry A. Padgett
}

Surveillance to investigate the wildlife-vector transmission cycle of the human pathogen Borrelia miyamotoi in California, USA, revealed infections in dusky-footed woodrats, brush mice, and California mice. Phylogenetic analyses suggest a single, well-supported clade of $B$. miyamotoi is circulating in California.

$B$ orrelia miyamotoi is a spirochete that causes a relapsing febrile illness and is transmitted by hard Ixodes species ticks $(1,2)$. B. miyamotoi is prevalent in western black-legged tick (I. pacificus) populations in California, USA $(3,4)$; in some locations, B. miyamotoi prevalence in ticks is comparable with or higher than the prevalence of the Lyme disease agent, B. burgdorferi sensu stricto (3-5). There is mounting evidence that human infections occur in northern California (6).

Surveillance of B. miyamotoi in California has focused on ticks, and little is known about infection in wildlife hosts. B. miyamotoi has been identified from spleen samples of birds and rodents in Europe (7), from blood and bladder samples of rodents in Japan (8), and from white-footed mice (Peromyscus leucopus) in the eastern United States (9). In California, surveillance in Alameda County (east of the San Francisco Bay) observed B. miyamotoi in tick populations but failed to detect the spirochete in mammals (10). We investigated $B$. miyamotoi infection status in small mammals at 3 California sites where the bacterium is present in tick populations $(3,5)$.

\section{The Study}

We captured animals on 2 consecutive nights at each of 3 sites in the San Francisco Bay area of California during June 2014: Windy Hill $\left(37.37315^{\circ},-122.22466^{\circ}\right)$ and Thornewood $\left(37.39086^{\circ},-122.25066^{\circ}\right)$ Open Space Preserves (OSP) in San Mateo County, and Foothills Park (37.36243, $-122.17362^{\circ}$ ) in Santa Clara County. We chose these sites on

Author affiliations: Colorado State University, Fort Collins,

Colorado, USA (D.J. Salkeld); Northern Arizona University,

Flagstaff, Arizona, USA (N.C. Nieto); California Department of

Public Health, Richmond, California, USA (D.L. Bonilla,

M.H. Yoshimizu, K.A. Padgett)

DOI: https://doi.org/10.3201/eid2412.171632 the basis of local B. miyamotoi prevalence of $3.6 \%-10.7 \%$ in I. pacificus nymphs (5). Trapping occurred in June to coincide with the peak abundance of nymphal black-legged ticks and so perhaps increase the chance that $B$. miyamoto $i$ would be circulating in animal populations (11). Animals were captured using Sherman live traps baited with peanut butter and oats.

We anesthetized captured animals with isoflurane, identified them by morphology using taxonomic guides, and examined them for ticks. We obtained blood and eartissue biopsy samples from each individual and tested both sample types for Borrelia spp. because different Borrelia species may vary in tissue tropism (9).

We extracted DNA from all samples (i.e., whole blood, ear punch biopsies, and ticks) using DNeasy Blood and Tissue Kits (QIAGEN, Valencia, CA, USA) and assayed for the presence of Borrelia using quantitative PCR (qPCR) (9), which is able to detect as few as 10 spirochetes. We sequenced all qPCR-positive samples using a primer set targeting the intergenic spacer rrs-rrlA locus, which allowed for differentiation of Borrelia genospecies (12). Alignments were made in ClustalX (http://www.clustal.org). We compared our sequences from I. pacificus ticks and wild-caught rodents (GenBank accession nos. MH342008-31) to representative GenBank sequences from isolates found in other sites in California (accession nos. KT343321, KT343334, KT343337, KU184505, KF957668), elsewhere in the United States (accession nos. HQ658901, HQ658902, AY374140, AY37139, AY374138, AY363706, GU993308, KY293400, KY293399, KY293398, KY293397, KY293396, GQ856588, GU993309, GQ856589), Japan (accession nos. AY363703, AY363704), and Sweden (accession no. AY363705). We conducted phylogenetic reconstruction using MrBayes (http://mrbayes.csit.fsu.edu/) and visualizations using FigTree (http:// tree.bio.ed.ac.uk/software/figtree/).

We captured a total of 117 small mammals from 5 species (Table 1). Our surveillance efforts demonstrate that $B$. miyamotoi infects woodrats (Neotoma fuscipes), brush mice (Peromyscus boylii), and California mice (P. californicus) (Table 2). At sites where B. miyamotoi was present in small mammals, $B$. miyamotoi prevalence was $6 \%-33 \%$ in different host species (Table 2). These data reflect B. miyamotoi prevalence in small-mammal hosts in other geographic

\footnotetext{
${ }^{1}$ These authors contributed equally to this article.

${ }^{2}$ Current affiliation: United States Department of Agriculture, Fort Collins, Colorado, USA.
} 
Table 1. Numbers of mammals captured and tested for Borrelia spp., by species and location, California, USA*

\begin{tabular}{|c|c|c|c|c|c|}
\hline \multirow[b]{2}{*}{ Species } & \multirow[b]{2}{*}{ Foothills Park } & \multicolumn{2}{|c|}{ Thornewood OSP } & \multirow[b]{2}{*}{ Windy Hill OSP } & \multirow[b]{2}{*}{ Total } \\
\hline & & $\begin{array}{l}\text { Redwood } \\
\text { habitat }\end{array}$ & $\begin{array}{l}\text { Oak-madrone } \\
\text { woodland }\end{array}$ & & \\
\hline Dusky-footed woodrat (Neotoma fuscipes) & 4 & 0 & 1 & 1 & 6 \\
\hline Brush mouse (Peromyscus boylii) & 27 & 9 & 17 & 18 & 71 \\
\hline California mouse (Peromyscus californicus) & 6 & 3 & 9 & 6 & 24 \\
\hline Deer mouse (Peromyscus maniculatus) & 6 & 4 & 2 & 1 & 13 \\
\hline Pinyon mouse (Peromyscus truei) & 3 & 0 & 0 & 0 & 3 \\
\hline Total & 46 & 16 & 29 & 26 & 117 \\
\hline
\end{tabular}

regions: $10.7 \%$ of voles and mice $(\mathrm{n}=65)$ in the Netherlands, where nymphal infection prevalence (NIP) of B. miyamotoi in I. ricinus ticks is $2.5 \%$ (84/3360) (7), and $6.5 \%$ of whitefooted mice ( $P$. leucopus) in the northeastern United States, where NIP in I. scapularis ticks is 5.5\% (38/689) (9). We did not observe $B$. miyamotoi in pinyon mice or deer mice, either because of small sample sizes or because these species are not involved in B. miyamotoi transmission. In nearby Alameda County, B. miyamotoi was not observed in small mammals (10); possible reasons are that the spirochete is rarer in this locality (NIP $=0.4 \%$ in Alameda study sites), that mammal capture periods were dispersed across multiple years and not as coincident with nymphal tick activity, or that brush mice and California mice were not captured at that location.

Other identified Borrelia species included B. bissettiae in 1 pinyon mouse ( $P$. truei) and 1 brush mouse, which mirrors earlier studies of $B$. bissettiae from farther north in California $(13,14)$. Woodrats, California voles (Microtus californicus), deer mice (P. maniculatus), and black rats (Rattus rattus) have also been observed infected with $B$. bissettiae $(10,13)$. During previous tick sampling efforts at our study sites, we did not detect $B$. bissettiae in questing western black-legged ticks $(3,5)$.

We did not find $B$. burgdorferi sensu stricto, although we observed uncharacterized B. burgdorferi sensu lato infection in 1 California mouse. None of the animals captured in the redwood habitat (Thornewood OSP) were infected with Borrelia spp., although the sample size was small at this location (Table 1). We found a co-infection of B. burgdorferi sl and B. miyamotoi in a brush mouse.
Co-infections of B. burgdorferi and B. miyamotoi have previously been reported from mice and ticks in the northeastern United States (9) and from ticks in Marin County, California (4).

Five mammals were infested with $I$. angustus ticks, of which we observed all 3 life stages. In redwood habitat at Thornewood OSP, 1 California mouse hosted 2 adult females and a nymph, 1 brush mouse was infested with 2 adult females and 2 nymphs, and 1 brush mouse carried 1 female and 1 nymphal tick. Of 2 brush mice captured at Windy Hill, 1 harbored 3 larvae and the other 5 larvae. None of the 17 I. angustus ticks tested positive for Borrelia spp., nor did the host animals from which the ticks were removed. We found no I. pacificus ticks infesting the small mammals.

Phylogenetic analyses suggest that $B$. miyamotoi in California is a single strain, separate from $B$. miyamotoi in the eastern United States and from strains circulating in Asia and Europe (Figure), corroborating an earlier study (15). Sequences from I. pacificus ticks previously collected in the San Francisco Bay area were identical to the sequences obtained from rodent infections.

\section{Conclusions}

The identification of B. miyamotoi in small mammals in California mirrors research from other locations that have documented the spirochete in small rodents. It is premature to claim these infected species as B. miyamotoi reservoirs (i.e., responsible for maintenance of the pathogen and acting as a source for of zoonotic transmission), in part because

\begin{tabular}{|c|c|c|c|c|c|}
\hline Borrelia species & Mammal species & Site & $\begin{array}{l}\text { Sample } \\
\text { source }\end{array}$ & $\begin{array}{l}\text { Prevalence at site, no. } \\
\text { tested/no. positive }(\%)\end{array}$ & $\begin{array}{l}\text { Prevalence across sites, } \\
\text { no. tested/no. positive (\%) }\end{array}$ \\
\hline \multirow[t]{5}{*}{ B. miyamotoi } & Dusky-footed woodrat & Foothills & Blood & $1 / 4(25)$ & $1 / 6(17)$ \\
\hline & Brush mouse & $\begin{array}{l}\text { Thornewood } \\
\text { woodland }\end{array}$ & Ear & $1 / 17(6)$ & $2 / 71(3)$ \\
\hline & Brush mouse* & Windy Hill & Ear & $1 / 18(6)$ & \\
\hline & California mouse & Foothills & Ear & $1 / 6(17)$ & $4 / 24(17)$ \\
\hline & California mouse & $\begin{array}{l}\text { Thornewood } \\
\text { woodland }\end{array}$ & 2 ear, 1 blood & $3 / 9(33)$ & \\
\hline \multirow[t]{2}{*}{ B. bissettiae } & Brush mouse & $\begin{array}{l}\text { Thornewood } \\
\text { woodland }\end{array}$ & Ear & $1 / 17(6)$ & $1 / 71(1)$ \\
\hline & Pinyon mouse & Foothills & Blood & $1 / 3(33)$ & $1 / 3(33)$ \\
\hline B. burgdorferi sensu lato & California mouse & Windy Hill & Blood & $1 / 6(17)$ & $1 / 24(4)$ \\
\hline $\begin{array}{l}\text { Borrelia spp., not } \\
\text { sequenced }\end{array}$ & Brush mouse & $\begin{array}{l}\text { Thornewood } \\
\text { woodland }\end{array}$ & $\begin{array}{l}2 \text { blood, } 1 \\
\text { blood and ear }\end{array}$ & $3 / 17(18)$ & $3 / 71(4)$ \\
\hline
\end{tabular}




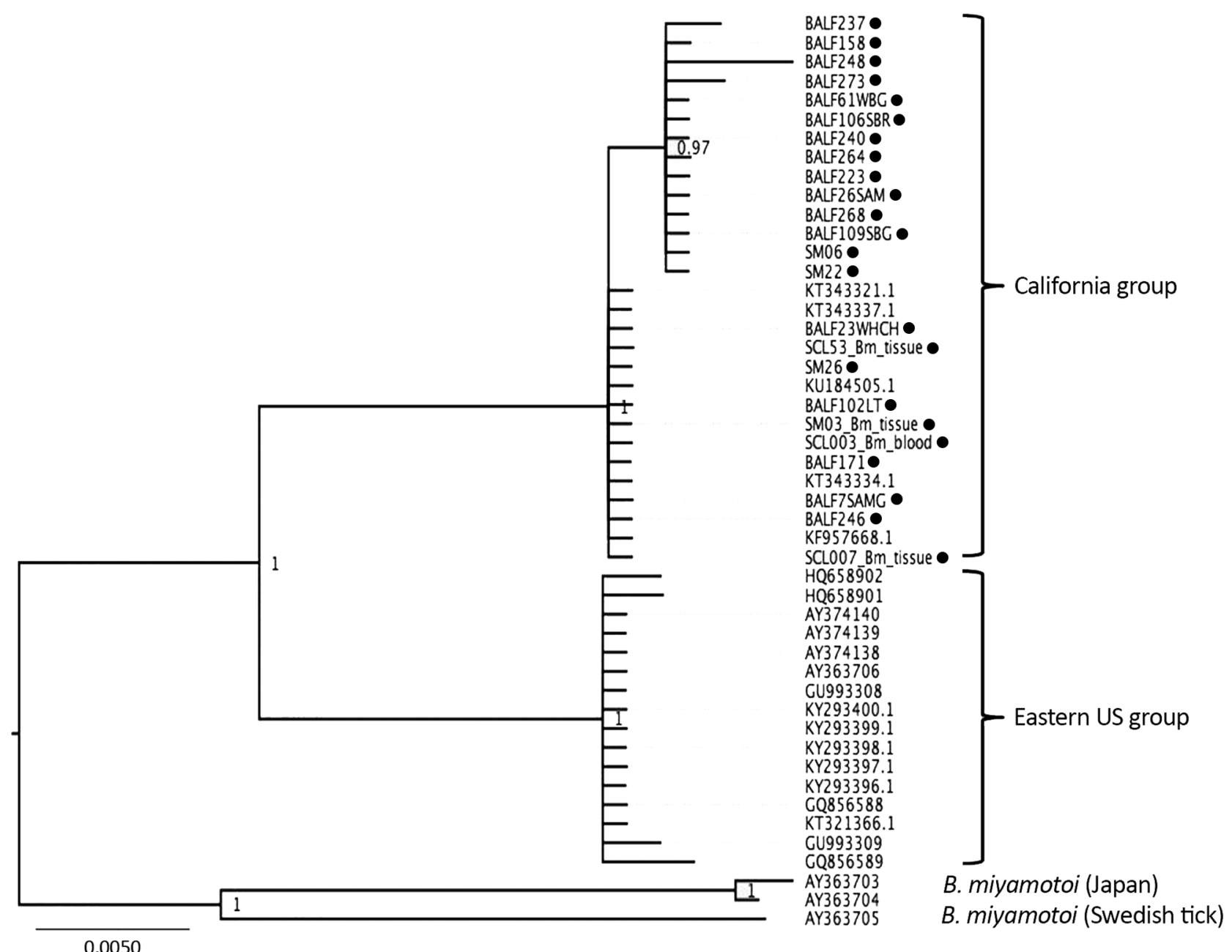

Figure. Phylogenetic tree of Borrelia miyamotoi intergenic spacer ( $r$ s-rrlA) sequences isolated from wild-caught rodents and ticks (black dots) from California, USA, in study of Borrelia spp. in small mammal species in the San Francisco Bay area, compared with reference samples from California, the eastern United States, Japan, and Sweden. Isolates are identified by isolate identification number or GenBank accession number. Scale bar indicates nucleotide substitutions per site.

B. miyamotoi can also be transmitted transovarially in the tick population; local maintenance of the spirochete may not require a reservoir host. Nonetheless, in California, where $B$. miyamotoi clusters into a single, well-supported phylogenetic clade, the spirochete appears to be circulating among rodent species. Xenodiagnostic investigation of these putative reservoir species, as well as more comprehensive investigations of the reservoir potential of other local fauna, including larger mammals (e.g., squirrels and deer) and birds, will further elucidate the ecology of B. miyamotoi in California.

\section{Acknowledgments}

We thank Foothills Park and the Midpeninsula Regional Open Space District for allowing us to conduct field research; Greg Hacker for help in the field; and W. Tanner Porter, Julie Wachara, and Thomas Lowrey for laboratory work.
This work was made possible by the generosity of the Bay Area Lyme Foundation.

\section{About the Author}

Dr. Salkeld at Colorado State University and Dr. Nieto at Northern Arizona University are interested in the ecology of tickborne diseases and the implications for human exposure and epidemiological risk.

\section{References}

1. Platonov AE, Karan LS, Kolyasnikova NM, Makhneva NA, Toporkova MG, Maleev VV, et al. Humans infected with relapsing fever spirochete Borrelia miyamotoi, Russia. Emerg Infect Dis. 2011;17:1816-23. http://dx.doi.org/10.3201/eid1710.101474

2. Krause PJ, Narasimhan S, Wormser GP, Rollend L, Fikrig E, Lepore T, et al. Human Borrelia miyamotoi infection in the United States. N Engl J Med. 2013;368:291-3. http://dx.doi.org/10.1056/ NEJMc1215469 
3. Salkeld DJ, Cinkovich S, Nieto NC. Tick-borne pathogens in northwestern California, USA. Emerg Infect Dis. 2014;20:493-4. http://dx.doi.org/10.3201/eid2003.130668

4. Padgett K, Bonilla D, Kjemtrup A, Vilcins I-M, Yoshimizu MH, Hui L, et al. Large scale spatial risk and comparative prevalence of Borrelia miyamotoi and Borrelia burgdorferi sensu lato in Ixodes pacificus. PLoS One. 2014;9:e110853. http://dx.doi.org/10.1371/ journal.pone. 0110853

5. Salkeld DJ, Nieto NC, Carbajales-Dale P, Carbajales-Dale M, Cinkovich SS, Lambin EF. Disease risk and landscape attributes of tick-borne Borrelia pathogens in the San Francisco Bay area, California. PLoS One. 2015;10:e0134812. http://dx.doi.org/ 10.1371/journal.pone. 0134812

6. Krause PJ, Carroll M, Fedorova N, Brancato J, Dumouchel C, Akosa F, et al. Human Borrelia miyamotoi infection in California: serodiagnosis is complicated by multiple endemic Borrelia species. PLoS One. 2018;13:e0191725. http://dx.doi.org/10.1371/ journal.pone. 0191725

7. Wagemakers A, Jahfari S, de Wever B, Spanjaard L, Starink MV, de Vries HJC, et al. Borrelia miyamotoi in vectors and hosts in the Netherlands. Ticks Tick Borne Dis. 2017;8:370-4. http://dx.doi.org/ 10.1016/j.ttbdis.2016.12.012

8. Taylor KR, Takano A, Konnai S, Shimozuru M, Kawabata H, Tsubota T. Borrelia miyamotoi infections among wild rodents show age and month independence and correlation with Ixodes persulcatus larval attachment in Hokkaido, Japan. Vector Borne Zoonotic Dis. 2013;13:92-7. http://dx.doi.org/10.1089/ vbz.2012.1027

9. Barbour AG, Bunikis J, Travinsky B, Hoen AG, Diuk-Wasser MA, Fish D, et al. Niche partitioning of Borrelia burgdorferi and Borrelia miyamotoi in the same tick vector and mammalian reservoir species. Am J Trop Med Hyg. 2009;81:1120-31. http://dx.doi.org/10.4269/ajtmh.2009.09-0208

10. Fedorova N, Kleinjan JE, James D, Hui LT, Peeters H, Lane RS. Remarkable diversity of tick or mammalian-associated Borreliae in the metropolitan San Francisco Bay area, California. Ticks Tick Borne Dis. 2014;5:951-61. http://dx.doi.org/10.1016/ j.ttbdis.2014.07.015

11. Salkeld DJ, Castro MB, Bonilla D, Kjemtrup A, Kramer VL, Lane RS, et al. Seasonal activity patterns of the western blacklegged tick, Ixodes pacificus, in relation to onset of human Lyme disease in northwestern California. Ticks Tick Borne Dis. 2014;5:790-6. http://dx.doi.org/10.1016/j.ttbdis.2014.05.002

12. Bunikis J, Garpmo U, Tsao J, Berglund J, Fish D, Barbour AG Sequence typing reveals extensive strain diversity of the Lyme borreliosis agents Borrelia burgdorferi in North America and Borrelia afzelii in Europe. Microbiology. 2004;150:1741-55. http://dx.doi.org/10.1099/mic.0.26944-0

13. Brown RN, Peot MA, Lane RS. Sylvatic maintenance of Borrelia burgdorferi (Spirochaetales) in northern California: untangling the web of transmission. J Med Entomol. 2006;43:743-51. http://dx.doi.org/10.1093/jmedent/43.4.743

14. Eisen L, Eisen RJ, Mun J, Salkeld DJ, Lane RS. Transmission cycles of Borrelia burgdorferi and B. bissettii in relation to habitat type in northwestern California. J Vector Ecol. 2009;34:81-91. http://dx.doi.org/10.1111/j.1948-7134. 2009.00010.x

15. Cook VJ, Fedorova N, Macdonald WP, Lane RS, Barbour AG. Unique strain of Borrelia miyamotoi in Ixodes pacificus ticks, California, USA. Emerg Infect Dis. 2016;22:2205-7. http://dx.doi.org/10.3201/eid2212.152046

Address for correspondence: Daniel J. Salkeld, Colorado State University, Department of Biology, 1878 Campus Delivery, Fort Collins, CO 80523, USA; email: dan.salkeld@colostate.edu

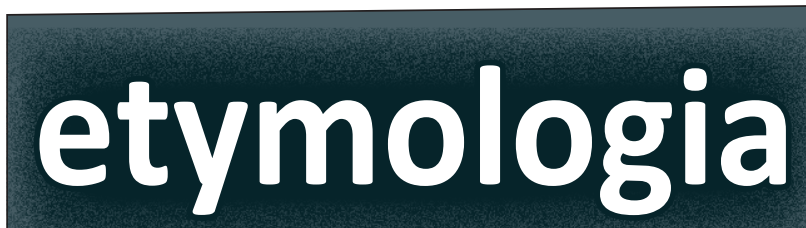

Etymology is

concerned with the

origin of words, how they've evolved over time, and changed in form and meaning as they

were translated from one language to another.

Every month, EID publishes a feature highlighting the etymology of a word from medicine or public health.

\section{featured monthly in} EMERGING INFECTIOUS DISEASES

\section{http://wwwnc.celc.gov/eid/ articles/etymologia}

